\title{
EFEKTIVITAS VAKSINASI Crude DAN Soluble Protein SPORA Myxobolus koi TERHADAP TINGKAT KERUSAKAN USUS IKAN KOI (Cyprinus carpio Koi)
}

\section{THE EFFECTIVETY Crude and Soluble Protein of Myxobolus koi SPORE AGAINTS INTESTINE DIFFERENT DEGREES IN KOI (Cyprinus carpio koi).}

\author{
Rachma Woro Anggarani, Gunanti Mahasri dan Lucia Tri Suwanti \\ Fakultas Perikanan dan Kelautan Universitas Airlangga \\ Kampus C Mulyorejo - Surabaya, 60115 Telp. 031-5911451
}

\begin{abstract}
Myxobolus koi is one species of Myxobolus sp that can cause parasitic diseases in fish called Myxobolusis. Based on the Decree of the Minister of Marine and Fisheries No: KEP.03/MEN/2010 that Myxobolus koi in the list of Fish Quarantine Pests group I. Myxosporean diseases are most numerous in the water can cause Proliferative Kidney Disease (PKD) and Whirling Disease (WD).

The aim of this research is to finding, analyzing and determining the protein of spores Myxobolus koi that can effectively reduce the level of damage to the intestinal organs as well as for the prevention myxobolusis on Koi's. Then for finding, analyzing and determining the protein of spores Myxobolus koi do isolation of spore proteins.

The study consisted of three phases examination to preparation and identification of spores, isolation and analyze of crude and soluble protein spores for obtain dose and molecular weight each protein and histopathological test. This research uses descriptive method. The data presented may be narratives, images, tables or charts for each group. Intestinal histopathology test results of research carried scoring Koi's were analyzed using the Kruskal-Wallis.

The results showed a profile crude protein and soluble proteins from spores Myxobolus koi showed that the molecular weight of crude protein Myxobolus koi in this study was $150 \mathrm{kDa}$ and $72 \mathrm{kDa}$ and for soluble protein was $73 \mathrm{kDa}$. Results scoring the degree of infection caused by exposure to Myxobolus koi then statistically processed with an average yield of scoring in a sequence of $0 ; 1.6 ; 0.64$ and 0.32 . Statistical analysis showed no significant difference in the treatment of $\mathrm{K}+$ with crude protein, and $\mathrm{K}+$ with soluble proteins. Statistical analysis showed that there were significant differences in treatment with $\mathrm{K}+$ and $\mathrm{K}-, \mathrm{K}-$ with soluble protein and crude protein and soluble protein. Histopathological changes in the intestine in the form of inflammatory cell infiltration, necrosis and haemorage
\end{abstract}

Keywords : Myxobolus, crude protein, soluble protein, histopathology, intestines, koi fish

\section{Pendahuluan}

Myxobolus koi merupakan salah satu spesies dari Myxobolus sp yang dapat menyebabkan penyakit parasiter pada ikan yang disebut Myxobolusis. Pada umumnya organisme penyebab penyakit ini bersifat sistemik serta dikenali dari morfologi spora, jumlah dan lokasi filamen polar (Mahasri, 2004).

Mahasri dan Kismiyati (2011) menjelaskan bahwa Myxobolus koi membentuk nodul pada insang yang berisi ribuan spora sehingga dapat menghalangi proses penyerapan oksigen serta sering menyebabkan operculum selalu terbuka. Jika nodul ini pecah, maka spora menyebar ke perairan sehingga tertelan oleh ikan akibat ukuran spora yang relatif kecil. Spora yang tertelan oleh ikan akan masuk kedalam usus kemudian melepaskan filamen polar untuk menancap pada dinding usus serta mengeluarkan sporoplasma untuk melakukan penetrasi pada mukosa usus dan mengikuti aliran darah menuju organ target yakni insang.

Usus adalah organ utama pencernaan makanan dan penyerapan nutrisi. Takashima and Hibiya (1995) menjelaskan bahwa struktur histologi dari dinding saluran pencernaan ikan terdiri dari empat lapisan dasar yakni mukosa, submukosa, muskularis dan serosa. Menurut Deloshoub et al (2010) lapisan mukosa usus memiliki banyak vili sepanjang anterior hingga posterior usus dan pada bagian mukosa inilah banyak ditemukan infeksi parasit.

Upaya pengobatan dengan menggunakan perendaman air laut maupun penggunaan bahan kimia seperti formalin, methylen blue, pottasium permanganate, glacial acetic acid atau phenol tidak efektif untuk 
mengobati penyakit yang diakibatkan oleh parasit Myxobolus koi (Schaperlaus, 1992).

\section{Materi dan Metode}

Tempat Pengambilan Sampel

Lokasi pengambilan sampel diambil dari kolam budidaya koi di Sentra Budidaya Koi Desa Kemloko Kecamatan Nglegok Kabupaten Blitar Propinsi Jawa Timur.

Pengambilan Sampel

Sampel ikan koi diperoleh dari kolam budidaya sebanyak 4200 ekor dengan kisaran panjang 5-7 cm dengan umur 2 bulan. Sampel diambil dari populasi ikan koi yang terinfeksi Myxobolus dengan berbagai tingkat infeksi dan ukuran nodul. Pembuatan preparat histopatologi diambil dari 5 ekor ikan untuk setiap perlakuan (Klinger and Floyd, 2002).

\section{Identifikasi Spora Myxobolus koi}

Karakteristik morfologi spora Myxobolus koi dapat dikenali berdasarkan bentuk spora, bagian spora dan jumlah kapsul polar. Cara identifikasi adalah dengan melakukan pengamatan terhadap spora yang terdapat dalam nodul pada insang ikan koi dengan metode natif melalui mikroskop cahaya dengan perbesaran 400x (Lom and Dykova, 1995)

Perhitungan Spora Myxobolus koi

Perhitungan spora dilakukan dengan menggunakan haemocytometer dan untuk memudahkan perhitungan digunakan hand counter. Perhitungan spora menggunakan metode "Big Block" karena ukuran spora Myxobolus koi yang lebih dari $6 \mu \mathrm{m}$ (Satyantini dkk., 2012).

Isolasi crude dan soluble protein spora Myxobolus koi

Spora yang telah dihitung kemudian dicuci dengan PBS dan disentrifugasi dengan kecepatan $5000 \mathrm{rpm}$ selama 10 menit. Proses pencucian diulang sebanyak 2 kali. Pelet diresuspensi dengan buffer lisis $(0,32 \mathrm{M}$ scrose (sucrosa) 54,8 gram, 1\% v/v Triton X-100 0,5 $\mathrm{ml}, 10 \mathrm{mM}$ Tris $H C L \mathrm{pH} 7,4$ sebanyak $10 \mathrm{ml}$ ) sehingga mendapatkan konsentrasi sebanyak \pm $11 \mathrm{ml}$. Kemudian pada suspensi pellet ditambahkan 0,5 ml EDTA $1 \mu \mathrm{M}$ dan PMSF (phenylmethylsulfonyl fluoride) $5 \mathrm{mM}$ sebanyak $0,5 \mathrm{ml}$. Kemudian dilakukan sonikasi dengan waterbath sonicator dalam es (1 menit sonikasi $1 / 2$ menit istirahat), dilakukan berulang 10 kali. Hasil sonikasi tersebut divortex ( $1 / 2$ menit vortex 1 menit istirahat) dalam es, dilakukan berulang
15 kali. Larutan hasil sonikasi merupakan crude protein (Ratnasari dan Wijayanto, 2005).

Setengah bagian (3cc) dari crude protein tersebut diproses dengan sentrifuge berkecepatan $10000 \mathrm{rpm}$ dalam 20 menit dengan temperatur yang rendah $\left(4^{0} \mathrm{C}\right)$ untuk mendapatkan soluble protein sedangkan pelletnya merupakan Outer Membrane Protein (Ratnasari dan Wijayanto, 2005).

Respons imun ikan Koi terhadap vaksinasi crude dan soluble protein spora Myxobolus koi.

Respons imun ikan Koi setelah di imunisasi dengan crude dan soluble protein spora Myxobolus koi diamati melalui tingkat kerusakan usus setelah pemaparan Myxobolus koi. Penelitian ini menggunakan 5 perlakuan. Ikan Koi di pelihara pada 5 akuarium dengan kapasitas 5 lt air. Tiap-tiap perlakuan dibagi menjadi 4 kelompok perlakuan (A1, A2, hingga C1).

Pemeriksaan Histopatologi

Pemeriksaan derajat kerusakan usus akibat infestasi Myxobolus koi dilakukan sebanyak 25 preparat histopatologi. Preparat diperiksa secara mikroskopis untuk mengetahui derajat kerusakan dengan skoring pada perubahan histopatologi yang terjadi untuk menentukan jenis dan tingkat kerusakan pada organ usus, dengan nilai $0,1,2,3$ dan 4 (Mahasri, 2007). Dasar skoring adalah nilai 0 diberikan pada preparat yang belum terjadi kerusakan pada satu lapang pandang (tidak ada perubahan patologi), nilai 1 diberikan pada preparat yang mengalami kerusakan kurang dari atau sama dengan 25 persen pada satu lapang pandang (tingkat kerusakan ringan), nilai 2 diberikan pada preparat yang mengalami kerusakan sebesar 26-50 persen pada satu lapang pandang (tingkat kerusakan sedang), nilai 3 diberikan pada preparat yang mengalami kerusakan sebesar 51-75 persen pada satu lapang pandang (tingkat kerusakan berat), nilai 4 diberikan pada preparat yang mengalami kerusakan lebih dari 75 persen pada satu lapang pandang (tingkat kerusakan sangat berat).

\section{Hasil dan Pembahasan}

Identifikasi Myxobolus secara mikroskopis dilakukan terhadap spora yang terdapat pada nodul di insang ikan koi dengan metode natif. Hasil pengamatan di laboratorium menunjukkan bahwa morfologi spora yang diamati sesuai dengan kunci identifikasi dari Lom and Dykova (2006) yaitu spora Myxobolus berbentuk elips atau oval. Di dalam spora Myxobolus terdapat dua kapsul polar berbentuk 

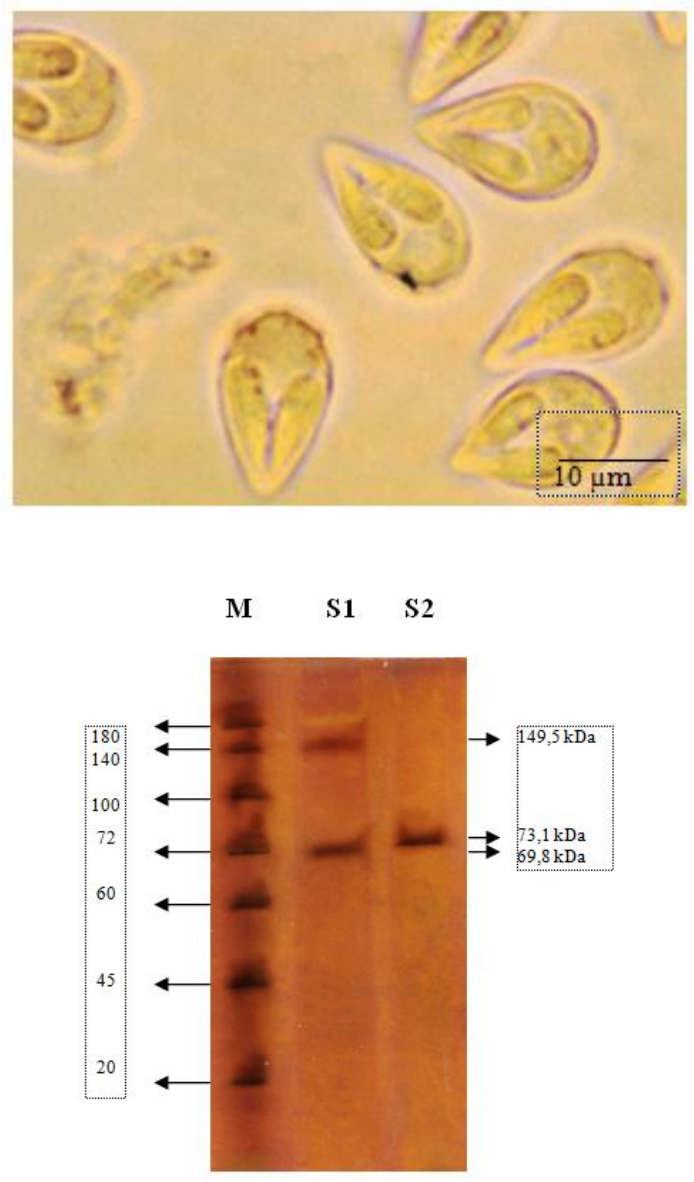

Gambar 1. Identifikasi Myxobolus koi pada insang ikan koi

pyriform yang terletak di bagian anterior. Pengamatan gejala klinis di kolam menunjukkan ikan koi yang terinfeksi Myxobolus antara lain ikan berenang mendekati permukaan air dan sulit bernafas akibat terdapat nodul berwarna putih kemerahan di filamen insang sehingga menyebabkan operkulum tidak dapat menutup.

Gambaran profil crude protein dan soluble protein dari spora Myxobolus koi menunjukkan bahwa berat molekul dari crude protein M.koi dalam penelitian ini adalah 150 $\mathrm{kDa}$ dan $72 \mathrm{kDa}$ dan untuk soluble protein M.koi adalah $73 \mathrm{kDa}$ serta konsentrasi protein crude protein sebesar $10,36 \mu \mathrm{g} / \mathrm{ml}$ dan soluble protein sebesar $8,68 \mu \mathrm{g} / \mathrm{ml}$.

Berdasarkan pengamatan histopatologi usus ikan mas yang terinfestasi $M$. koi dengan perlakuan yang berbeda yaitu terdapat kerusakan histopatologi berupa nekrosis, infiltrasi sel radang, dan ditandai dengan adanya spora $M$. koi pada jaringan usus.
Daur hidup dari Myxobolus koi antara lain masuknya spora ke dalam saluran pencernaan ikan koi. Berdasarkan pemeriksaan yang telah dilakukan secara mikroskopis telah terbukti adanya spora yang ditemukan dalam usus ikan koi dengan jumlah berbeda pada tiap vaksinasi protein dan diperiksa pada hari ke 4 pasca pemaparan spora. Derajat kerusakan usus ikan koi tiap perlakuan ditentukan dengan cara skoring untuk semua jenis kerusakan. Perubahan histopatologi usus dengan skoring. Hasil skoring derajat infeksi akibat pemaparan Myxobolus koi kemudian diolah secara statistik dengan hasil rata-rata skoring secara berurutan yaitu $0 ; 1,6 ; 0,64$ dan 0,32 . Analisis statistik menunjukkan tidak terdapat perbedaan yang signifikan pada perlakuan $\mathrm{K}+$ dengan crude protein, dan $\mathrm{K}+$ dengan soluble protein. Analisis statistik menunjukkan terdapat perbedaan yang signifikan pada perlakuan $\mathrm{K}+$ dengan $\mathrm{K}-$, $\mathrm{K}$ dengan soluble protein serta crude protein dan soluble protein. 

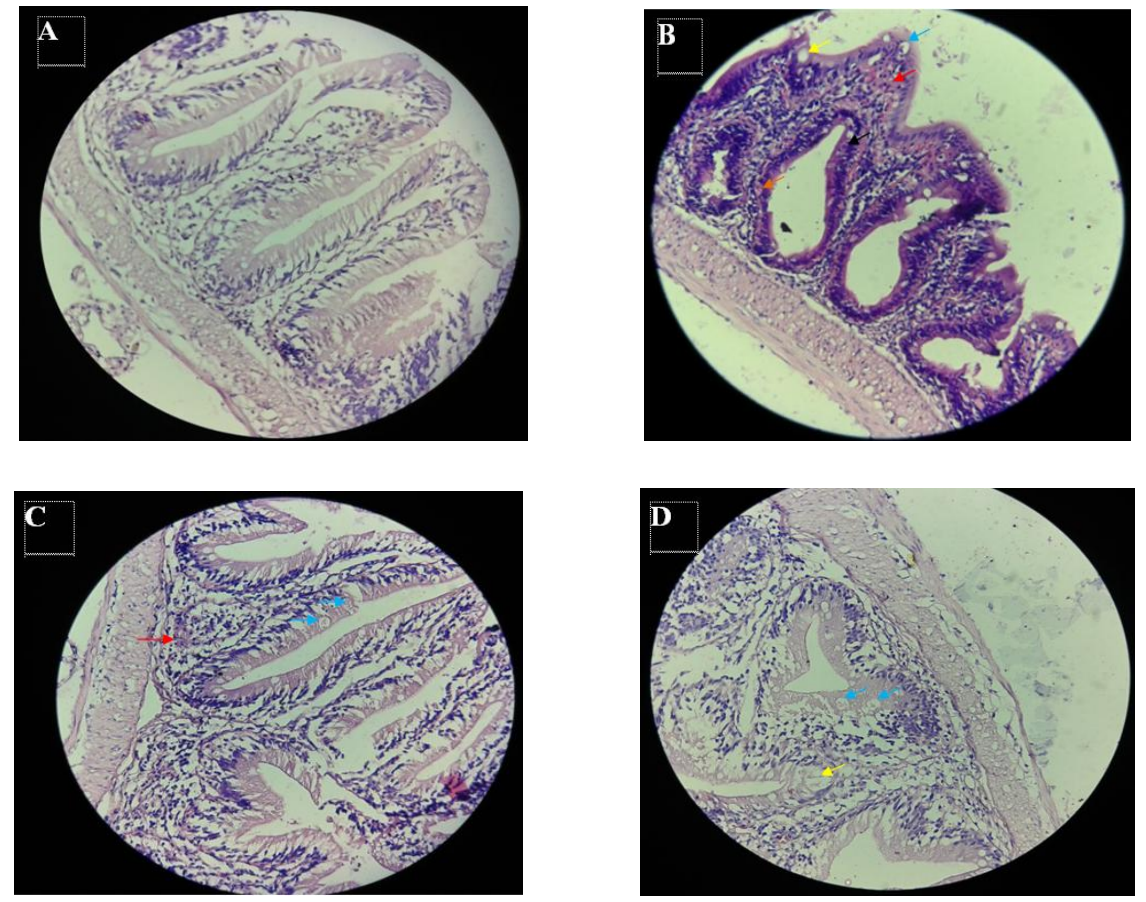

Gambar 2. Histologi usus ikan koi. A adalah K-(normal), B adalah K+, C adalah B1, D adalah C1. Panah kuning $(\rightarrow)$ ) menunjukkan nekrosis (kariolisis), panah orange $(\rightarrow$ ) menunjukkan nekrosis (piknosis), panah biru $(\longrightarrow$ ) menunjukkan nekrosis (karioreksis), panah merah $(\longrightarrow)$ ) menunjukkan infiltrasi sel radang (IR), panah hitam $(\rightarrow)$ menunjukkan kista M.koi,. Pewarnaan HE, Pembesaran 400x. Bar: 40 $\mu \mathrm{m}$.

Hasil skoring derajat infeksi akibat pemaparan Myxobolus koi kemudian diolah secara statistik dengan hasil rata-rata skoring secara berurutan yaitu $0 ; 1,6 ; 0,64$ dan 0,32 . Analisis statistik menunjukkan tidak terdapat perbedaan yang signifikan pada perlakuan $\mathrm{K}+$ dengan crude protein, dan $\mathrm{K}+$ dengan soluble protein. Analisis statistik menunjukkan terdapat perbedaan yang signifikan pada perlakuan $\mathrm{K}+$ dengan K-, K- dengan soluble protein serta crude protein dan soluble protein. Skoring Histopatologi dapat dilihat pada tabel.1

Tabel 1. Pengamatan Histopatologi Usus Ikan Koi Akibat Infeksi Myxobolus koi pada tiap perlakuan

\begin{tabular}{ccc}
\hline Perlakuan & $\begin{array}{c}\text { Median } \\
\text { Skoring }\end{array}$ & $\begin{array}{c}\text { Rata- Rata } \\
\text { Skoring }\end{array}$ \\
\hline A1 (K-) & 0 & $0^{\mathrm{a}}$ \\
A2 (K+) & 2 & $1,6^{\mathrm{b}}$ \\
B1 & 1 & $0,64^{\mathrm{c}}$ \\
C1 & 0 & $0,32^{\mathrm{d}}$ \\
\hline
\end{tabular}

Data pengukuran kualitas air pada kolam budidaya saat pengambilan sampel di Desa Kemloko, Kecamatan Nglegok, Kabupaten Blitar menunjukkan suhu rata-rata kolam adalah $28^{\circ} \mathrm{C}, \mathrm{pH}$ rata-rata air kolam adalah 6 , kadar ammonia $0 \mathrm{mg} / \mathrm{l}$, salinitas satu ppm, dan oksigen terlarut $9 \mathrm{mg} / \mathrm{l}$. Hal ini menunjukkan bahwa kondisi kualitas air kolam ikan koi di Desa Kemloko Kecamatan Nglegok Kabupaten Blitar dalam kondisi normal meskipun beberapa kondisi kualitas air pada kolam ikan koi tersebut tidak sesuai atau tidak berada dalam kisaran normal bagi kelangsungan hidup ikan koi.

Kualitas air yang baik sangat penting dalam budidaya ikan sebab kualitas air yang baik dapat memberikan hasil yang optimal pada budidaya ikan. Kualitas air dipengaruhi oleh berbagai zat-zat kimia yang terlarut dalam air antara lain suhu, $\mathrm{pH}$, dan oksigen terlarut. Data kualitas air media pemeliharaan sebelum dan sesudah perlakuan disajikan pada Tabel 3 .

Data hasil pengukuran suhu, $\mathrm{pH}$ dan oksigen terlarut pada media pemeliharaan ikan koi sebelum dan sesudah perlakuan menunjukkan sedikit perbedaan yakni $\mathrm{pH}$ air 
Tabel 2. Data Kualitas Air Media Pemeliharaan Sebelum dan Sesudah Perlakuan

\begin{tabular}{|c|c|c|c|c|c|c|c|c|c|}
\hline \multirow{3}{*}{ No. } & \multirow{3}{*}{$\begin{array}{c}\text { Media } \\
\text { Pemeliharaan }\end{array}$} & \multicolumn{8}{|c|}{ Parameter } \\
\hline & & \multicolumn{4}{|c|}{ Sebelum Perlakuan } & \multicolumn{4}{|c|}{ Sesudah Perlakuan } \\
\hline & & $\begin{array}{l}\text { Suhu } \\
\left({ }^{\circ} \mathrm{C}\right)\end{array}$ & $\mathrm{pH}$ & $\begin{array}{c}\text { DO } \\
(\mathrm{ppm})\end{array}$ & $\begin{array}{c}\mathrm{NH}_{3} \\
\text { (ppm) }\end{array}$ & $\begin{array}{l}\text { Suhu } \\
\left({ }^{\circ} \mathrm{C}\right)\end{array}$ & $\mathrm{pH}$ & $\begin{array}{c}\text { DO } \\
\text { (ppm) }\end{array}$ & $\begin{array}{c}\mathrm{NH}_{3} \\
\text { (ppm) }\end{array}$ \\
\hline 1. & A1 (K-) & 27 & 8 & 5 & 0 & 27 & 7 & 4 & 0 \\
\hline 2. & $\mathrm{~A} 2(\mathrm{~K}+)$ & 27 & 8 & 5 & 0 & 27 & 8 & 5 & 0,5 \\
\hline 3. & B1 & 27 & 8 & 5 & 0 & 27 & 6 & 4 & 0,5 \\
\hline 4. & $\mathrm{C} 1$ & 27 & 8 & 5 & 0 & 27 & 6 & 4 & 0,5 \\
\hline & Rerata & 27 & 8 & 5 & 0 & 27 & 6,5 & 4,2 & 0,5 \\
\hline
\end{tabular}

sebelum perlakuan sebesar 8 sedangkan setelah perlakuan sebesar 6,5 dan oksigen terlarut sebelum perlakuan sebesar 5 ppm sedangkan setelah perlakuan sebesar 4,2 ppm.

\section{Kesimpulan}

Kondisi kualitas air media pemeliharaan sebelum dan setelah perlakuan berubah dikarenakan adanya kontaminasi lingkungan akibat pemaparan spora Myxobolus koi dan adanya hasil ekskresi metabolisme ikan setelah pemberian protein crude dan soluble melalui injeksi.

\section{Daftar Pustaka}

Chavda, D., S. Bhatt., R.A. Sreepada and A. Sheth. 2010. Pathogenicity of Myxobolus koi Infection and its Effect on Protein Expression in Catla catla in Central Gujarat Region. Journal of Cell and Tissue Research Vol 10(1): 21572164.

Delashoub, M., I. Pousty and S. M. B. Khojasteh. 2010. Histology of Bighead Carp (Hypophthalmichthys nobilis) Intestine. J. Global Vet. 5(6):302-306.

Fajriah, A. Karakterisasi Protein Lernea sp. Dengan menggunakan metode SDSPAGE. Surabaya. 2009. Hal. 38-40.

Klinger, R.E and R.F. Floyd. 2002. Introduction to Freshwater Fish Parasites. Institute of Food and Agricultural Sciences. University of Florida. Florida. 13p.

Lom, J and I. Dykova. 1995. Myxozoan Genera: Definition and Notes on Taxonomy, Life Cycle, Terminology and Pathogenic Species. J. Folia Parasitologica 53:1-36.

Mahasri, G. 2004. Ilmu Penyakit Ikan Protozoa pad Ikan dan Udang. Fakultas Perikanan dan Kelautan Universitas Airlangga. Surabaya. Hal 25-29.
Mahasri, G. 2007. Protein Membran Imunogenik Zoothamnium penaei Sebagai Bahan Pengembangan Imunostimulan pada Udang Windu terhadap Zoothamniosis. Disertasi Program Pascasarjana. Universitas Airlangga. Hal 284.

Mahasri, G. dan Kismiyati. 2011. Buku Ajar Parasit dan Penyakit Ikan I (Ilmu Penyakit Protozoa dan Udang). Universitas Airlangga, Surabaya. Hal 3-4.

Noga, E. J. 2010. Fish Disease: Diagnosis and Treatment. Wiley-Blackwell; Second edition. p.242-243.

Plumb J. A. 1994. Health Maintenance and principal Microbial Diseases of Cultured Fishes. Iowa State University CRC Press, Boca Raton, Florida. p.144.

Plumb, J. A. and Hanson, L. A. 2011. Health Maintenance and Principal Microbial Disease of Cultured Fishes. $3^{\text {th }}$ Edition. Blackwell. Singapore. p. 39-45.

Ratnasari., R. H.E. Narumi, dan Wijayanto.,S. 2005. Isolasi dan Pengukuran Berat Molekul Protein Outer Membrane Protein (OMP) Kuman Salmonella pullorum Isolat Lapangan. Skripsi. Fakultas Kedokteran Hewan. Universitas Airlangga. Hal 28.

Rukyani, A. 1990. Histopathological Changes in The Gill of Common Carp (Cyprinus carpio L.) Infected with the Myxosporean Parasite MyxobolusKoi Kudo, 1920. Asian Fisheries Science (3):337-341.

Satyantini, W. H., E. D. Masithah, M. A. Alamsjah, Prayogo dan S. Andriyono. 2012. Penuntun Praktikum Budidaya Pakan Alami. Universitas Airlangga. Surabaya. hal. 49. 
Schaperlaus, W. 1992. Fish Disease. Vol.2. Schaperlaus, W, H. Kulow, K., Schereckenbach, K. (Eds.), A.A. Balkema. Rotterdam. p. 245.
Takashima, F. And T. Hibiya. 1995. An Atlas of Fish Histologi: Normal and Pathological Features. $2^{\text {nd }}$ Edition. Kodansha. Tokyo. p.67-68, pp.88-90. 